European Journal of Accounting, Auditing and Finance Research

Vol.10, No. 2, pp.52-63, 2022

Print ISSN: 2053-4086(Print),

Online ISSN: 2053-4094(Online)

\title{
ACCOUNTING RESTATEMENTS, MULTIPLE DIRECTORSHIPS AND RELATED PARTY TRANSACTIONS
}

\author{
Sunday Otuya \\ Department of Accounting, \\ Edwin Clark University, Kiabgodo, Delta State, Nigeria \\ Dheseviano Emiaso, \\ Department of Accounting, \\ Faculty of Management Sciences,Nnamdi Azikiwe University, Awka, Nigeria
}

Citation: Sunday Otuya and Dheseviano Emiaso (2022) Accounting Restatements, Multiple Directorships and Related Party Transactions, European Journal of Accounting, Auditing and Finance Research, Vol.10, No. 2, pp.5263

\begin{abstract}
The study was carried out to examine multiple directorship and related party transactions as they relate to the incidence of accounting restatement in Nigeria. The scope of the study was financial statements of 14 listed industrial goods companies for the period 2011 to 2020. The study, anchored on the Agency Theory obtained data from secondary sources through content analysis of financial statements. Findings of the study show that related party transactions have a positive and significant association with accounting restatement. The study further revealed that multiple directorship and firm profitability have a positive but not significant association with the incidence of accounting restatement among listed industrial goods companies in Nigeria. The study concludes that both board attributes of multiple directorship and firm operational characteristics such as related party transactions and profitability are important in determining the incidence of accounting restatement. The study recommends that firms should encourage sound corporate governance mechanisms to enhance effective monitoring and internal control processes to minimize the incidence of accounting misstatements.
\end{abstract}

KEYWORDS: accounting restatements, corporate reports, multiple directorship, related party transactions.

\section{INTRODUCTION}

Financial statements provide the relevant accounting information which enables users to identify and appraise investment opportunities with minimal errors, thus enhances a better allocation of economic resources. Clarity of information in the financial statement also reduces information asymmetry which by extension mitigates agency conflicts between managers and shareholders (Otuya, Ofeimun, \& Akporien, 2019; Rocha, Pereira, Bezerra, \& Nascimento, 2012). However, for financial statements to accomplish its purposes, information presented in a them needs to satisfy the fundamental qualitative characteristics of reliability and timeliness. Due to the reliance

ECRTD-UK: https://www.eajournals.org/ 
on the financial statement for corporate, business and investment decision making, a flawed or fraudulent financial report is capable of misleading users to make a wrong judgement or decision. Restatement in financial reporting occurs when a company corrects a major mistake in prior financial statements. A restatement is an indicator that financial information reported in the preceding financial statement contains an error and is inaccurate. The implication of accounting restatement is that actions taken by users based on previous accounting report may also be affected (Hasnan, Razali \& Hussain, 2020).

In Nigeria, the preparation and presentation of financial statements are guided by the Financial Reporting Council of Nigeria, the Nigeria Codes for Corporate Governance, and the Corporate Affairs Commission through the FRC Act (2014), NCCG (2018) and CAMA (2020) respectively. Since adoption of the International Financial Reporting Standards (IFRS in Nigeria, companies have been preparing their financial statements in compliance with IFRSs. However, these principles and standards offer flexibility to companies with a number of accounting preparation and presentation options. These accounting policy options provide the platform for companies to window-dress corporate financial statements, which also increases the incidence of restatement at a future period (Okeoma \& Kiabel, 2020; Enofe, Mgbame, Otuya \& Ovie, 2013; Utari, Rustiarini $\&$ Dewi, 2021; Velte, 2021).

The practice of accounting restatement, by implication, indicates a solemn failure of financial reporting, and clearly, can to a large extent affect key stakeholders, markets, institutions, and organisations. According to Rasyid and Ardana (2014), restatement of corporate financial statement is the most visible indicator of inappropriate accounting reporting. A financial statement restatement is also a clear signal that a firm's previous financial reports were unreliable and of poor quality (Anderson \& Yohn, 2002; Schroeder, 2001). However, in spite of the introduction of several governance mechanisms by the regulators, reported cases of financial statement manipulation, window-dressing, and fraud are rife and still persists (Abdulmalik \& Ahmad, 2016; Badawi, 2008; Okolie \& Agboma 2008; Odia, 2007; Enofe et al., 2013). Eventually, such windowdressing and manipulation practices lead to the likely occurrence of financial statement restatement. This has been proven through financial reporting issues in Nigeria, such as the IBTC Holdings sanction by the Financial Reporting Council in 2015 for misleading reports (Okeoma \& Kiabel, 2020), and Cadbury Nigeria governance reporting scandal (Okolie \& Agboma 2008). These companies at different times were engulfed in financial scandals and window dressing practices and had to correct and reissue their financial statements.

The implementation of company governance processes such as board independence, audit committee's expertise, audit committee independence, audit committee activities, external auditors' independence, auditor's size, and firm age, size, profitability, leverage, liquidity etc. have been reported to either mitigate or induce the occurrence of corporate financial restatement (Utari, Rustiarini \& Dewi, 2021). For example, the Nigeria Codes for Corporate Governance (NCCG) (2018) and the Companies and Allied Matters Act (CAMA) (2020) provide control instruments and frameworks which can help corporate organisations attain their goals as well as measures to

ECRTD-UK: https://www.eajournals.org/ 
prevent undesirable conflicts. Jehu and Ibrahim (2020), Ibrahim, Bello and Kargi (2015), and Velte (2021) highlighted the consequences of poor company's governance and financial reporting processes to include fraud, bankruptcy and liquidation, earnings manipulations and restatements, fall in company stock prices, loss of credibility in the public, loss of business partners, and loss of customers goodwill.

However, despite a plethora of studies on the role of governance structures and firm specific characteristics in addressing corporate financial statement restatement, there is a dearth of studies especially in the context of Nigeria industrial goods companies. While some recent studies (Olusola \& Abdulasisi, 2020; Okeoma \& Kiabel, 2020; Jehu \& Ibrahim, 2020; Ukarin, 2021), although relatively few in Nigeria, have added to the understanding of corporate financial statement restatement, the key argument in this study is the introduction of a unique structural attributes of multiple directorship and related third-party transactions which have been rarely investigated in prior studies.

\section{LITERATURE REVIEW AND HYPOTHESES DEVELOPMENT}

\section{Multiple Directorships and Accounting Restatements}

Multiple directorships is defined as a situation where a members of a corporate board is serving as board member of two or more other firms. The individual who occupies membership of multiple boards of companies is referred to as a multiple director. According to Beasley (1996), multiple directorships provide insights into how other companies pursue new approaches to business, expose directors to economic trends and aspects of diverse industries, give directors the chance to compare management practices and policies and, provide the exposure to directors regarding different management styles.

However, Morck, Shleifer, and Vishny (1988) contend that an individual sitting on too many external boards may results in directors being too busy to monitor management. Morck, Shleifer, and Vishny further state that multiple directorships encourage the tendency to be involved in activities that promote personal benefits, enhance empire building amongst the companies. Multiple engagements could lead to distraction, which could prevent them from their major monitoring role thus leading to financial statement errors or misstatements. While it is arguable that multiple directorships assist to increase directors' range of experience with the subsequent result of aiding their efficiency in performing their duties on the board, the fact that it could bring about conflict of interest when a person sits on the board of two or more competing companies cannot be ignored (Barzuza \& Quinn, 2017; Fich \& Shivdasani, 2006).

Multiple directorships is one of the provisions in the Companies and Allied Matters Act (CAMA) (2020) which is expected to contribute to the ease of doing business in Nigeria. Section 281 of the act allows for an individual to be a board member of more than one company. CAMA (2020) also stipulates a limit on multiple directorships of public firms by emphasizing that no person should be a director in more than five (5) publicly quoted firms at the same time. Prior to enactment of

ECRTD-UK: https://www.eajournals.org/ 
CAMA 2020, principle 2.8 of the Nigerian Code of Corporate Governance (NCCG) (2018) emphasized on the issue of multiple directorships. NCCG (2018) prescribes that a director should not serve simultaneously on too many corporate boards so as not to interfere with their ability to discharge their responsibilities. However, while the NCCG made provision for multiple directorships, it disqualifies same where the firms involved are competing firms. Pfeffer and Salancik (1978) opine that multiple directorship, benefits a company in four ways (1) providing counsel and professional advice; (2) enhancing legitimacy; (3) improving communication channels; and (4) mobilization of resources.

Few empirical studies have been conducted in response to multiple directorships. The argument in the literature is that while some companies benefit from the presence of multiple directorships on board, others may actually experience negative effect. Srinivasan and Richardson (2005) claim that companies that have multiple directors on their board experience better quality of financial reporting because of enhanced monitoring activities. Velte (2021) in a study on multiple directorships found that directors with many outside directorships is a symbol of "reputation", possessing the required experience, abilities, skills and knowledge to perform his duty thereby promoting corporate transparency.

Carpenter and Westphal (2001) explore the "Reputation" hypothesis and report that as the number of multiple directors on boards increases, companies are expected to enjoy the advantage from the skills, experience, and knowledge of such multiple directors. Multiple board appointments are expected to add value to a company by sharing their knowledge, expertise, and experience acquired because such directors are determined to enhance or preserve their reputation by providing sound and effective professional advice. However, consistent with the busyness hypothesis, Fich and Shivdasani (2006) contend that with higher number of board seats of a director, there is the tendency for the director to be "overloaded" and overstretched. Consequently, Fich and Shivdasani (2006) stress that firms with "busy" directors are less effective due to the expanded time commitment related to having multiple board appointments and likely to negatively affect the corporate financial reporting which in turn increases the likelihood of restatement of accounting reports.

Elyasiani and Zhang (2015) in a study found that bank holding companies with a larger proportion of multiple directorships experienced better financial reporting quality and less incidence of accounting and earnings restatement. Baccouche, Hadriche, and Omri (2014) found that boards in which many of the independent directors hold three or more directorships are associated with frail corporate governance and poor financial reporting quality with in turn increases the possibility of accounting restatement. Hasnan and Marzuki (2017) explore the effects of board characteristics on financial restatement. using multiple directorships, as one of the study's independent variables. The study was conducted using a sample of 76 restatement firms and 152 non-restatement Malaysian firms for the period 2006 to 2013. Findings of the study indicated cross directorships are significantly correlated with the financial restatement incidents. 
Uniamikogbo, Babatolu, and Oyewo (2014) in a study of Nigeria companies sought to investigate the interrelation between audit committee multiple directorship and financial reporting quality. A survey research design, using questionnaire as the research instrument to harvest the views of stakeholders of publicly quoted companies on the subject was adopted for the study. Findings of the study indicated that audit committee multiple directorships impact the quality of corporate financial reporting thereby reducing the likelihood of restatement of corporate financial reports. Against this backdrop, we frame our first hypothesis thus:

Hypothesis One: There is a significant positive relationship between multiple directorship and accounting restatement.

\section{Related Party Transactions and Accounting Restatements}

Related party transaction is defined by Gordon, Henry, and Palia (2004) as the transactions between the reporting entity and their related parties. A related party transaction according to IAS 24 of the International Financial Reporting Standards (IFRS) is a transfer of economic resources, services or obligations between a reporting entity and a related party, irrespective of whether a price is charged. Regulators and standard setters have cautioned oversight over related party transactions by making it mandatory for extensive disclosures. The need for disclosures is based on the assumption that information about the related parties would be useful to investing public to assess efficacy (Henry, Gordon, Reed \& Louwers 2012).

From the Agency theoretical perspective, there are two opposing views of the effects of related party transactions on accounting reporting: the conflict of interest view and the efficient transaction view. The conflict-of-interest perspective emphasizes the regulators' viewpoint of related party transactions as inefficient transactions not following the arm's length rule which encourages compromise in the management's responsibility to shareholders as agents (Gordon et al., 2004). The efficient transaction hypothesis, is the second view, which contends that related party transactions are efficient business transactions as they have the tendency to reduce the transaction cost and enable cordial activities between the parties exercising the economic demands of a firm operating in difficult institutional environments (Khanna \& Palepu, 2000). The Institute of Chartered Accountants of Nigeria (ICAN) (2014) warns that related parties and related party transactions could give rise to higher risks of material misstatements of the financial statements. The implication of ICAN caveat, is that higher volume or value of related party transaction could result in the higher incidence of corporate financial restatements as a result of likelihood of material misstatements.

A few studies that have investigated the relationship between restatement and related party transaction have come up with diverse results. For instance, Henry, Gordon, Reed, and Louwers (2012) in a Malaysian study observed that related party transactions have the tendencies of increasing the risks of material misstatements of the financial reports thus, could lead to the more incidence of restatements. Mahenthiran (2020) examined the harmonizing roles of board governance affecting misstatements using a sample of 104 Chilean listed firms over seven years.

ECRTD-UK: https://www.eajournals.org/ 
The study found that given the commonness of related party transactions in multinationals, there is a higher chance of restatement of financial reports. Kohlbeck, and Mayhew (2017) in a study revealed that, for the Standard \& Poor companies in the US, related party transactions have a significant connection with future accounting misstatements and higher likelihood of restatement of the financial accounts when associated firms are involved in related party transactions. In view of the above, we frame our second hypothesis thus:

Hypothesis Two: There is a significant negative relationship between related party transactions and accounting restatement.

\section{Control Variable Profitability}

Firm profitability as a firm structure variable is an important going concern assumption in assessing the financial reporting practices of the firm According to Efendi et al. (2007), when a company's profitability decreases, its financial trouble develops, and it is more likely to restate its previously published financial statistics. When a company's financial status deteriorates, it is common for the company's profits to be overstated as a result of a misrepresentation. Managers may also inflate results to show the firm as successful, dissuade a rise in the cost of capital, and avoid breaking a debt covenant (Efendi et al., 2007). According to Peterburgskey (2012), businesses with poor returns are more likely to restate their financial statements than those with high returns.

\section{METHODOLOGY}

\section{Design, Sampling and Data}

This study adopted both cross-sectional and longitudinal research designs. The cross-sectional design is appropriate since it entails gathering data on multiple cases across different firms. On the other hand, the longitudinal design is considered appropriate for this study since it facilitates measurement of accounting restatement trends from data collected for ten (10) years starting from 2011 to 2020. Seventeen (17) industrial goods companies that are listed on the NSE as at $31^{\text {st }}$ December 2020 (NSE, 2021) constitute the population of this study. However, the sample size of 16 was derived using the Yamane (1967) statistical formula:

$$
\mathrm{n}=\quad \stackrel{\mathrm{N}}{1+\mathrm{N}(\mathrm{E})^{2}}
$$

Where: $\mathrm{n}=$ sample size, $\mathrm{N}=$ Population size, and $\mathrm{e}=$ Level of significance desired.

Data for the study covered firms' annual reports for the years 2011-2020 for the sampled sixteen (16) companies in the industrial goods sector representing one hundred and sixty (160) year-endobservations. 


\section{Theoretical Framework and Model Specification}

Considering the aim of the study which is to examine the relationship between accounting restatements, multiple directorships and related party transactions, the agency theory is considered appropriate for the study. The fundamental underpinning of the agency theory is how to mitigate the conflict of interest that arises due to the separation of ownership (principals/shareholders) from control (agents/managers). According to Jensen and Meckling (1976) who are proponents of the agency theory, shareholders will make sure that the managers act in line with the objectives of the firm by giving the managers incentives and putting monitoring mechanisms in place. This is because in the absence of these, there could be weak governance and poor financial reporting. Ineffective corporate governance processes and managers motives are indicators of accounting misstatements and restatements thus validating the adoption of the agency theory for this study. Against this backdrop, a model that expresses accounting restatements as a function of multiple directorships and related party transactions is stated as follows:

$\mathrm{RES}_{\mathrm{it}}=\beta_{0}+\beta_{1} \mathrm{MDS}_{\mathrm{it}}+\beta_{2} \mathrm{RPT}_{\mathrm{it}}+\beta_{3} \mathrm{PFT}_{\mathrm{it}}+\varepsilon \mathrm{it}$

Where: RES: Incidence of Accounting Restatements; MDS: Multiple Directorships; RPT: Related Party Transactions; PRF: Profitability; $\beta_{1^{-}} \beta_{3}$ are Regression Parameters and $\varepsilon$ is error term; i represents sampled companies $(1,2,3, \ldots \ldots .16)$ while $t$ is the time dimension $(1,2,3, \ldots . .10)$.

Presumptively, we expect $\beta_{1}$ to be $>0$ which signifies a positive relationship of multiple directorships while $\beta_{2}$ and $\beta_{3}$ are expected to be $<0$ indicating a negative association of related party transactions and firm's profitability with accounting restatement.

Tabel 1: Measurement of Variables

\begin{tabular}{|l|l|l|l|l|l|}
\hline SN & Variable & Acronym & Measurement & Source & $\begin{array}{l}\text { A Priori } \\
\text { Expectation }\end{array}$ \\
\hline 1 & $\begin{array}{l}\text { Accounting } \\
\text { Restatement }\end{array}$ & RES & $\begin{array}{l}\text { A dichotomous variable of 1 if the word } \\
\text { "restate", "prior year adjustment" or } \\
\text { "accounts reclassification" is used, and } \\
\text { 0 if otherwise. }\end{array}$ & $\begin{array}{l}\text { Hasnan, } \\
\text { Razali, and } \\
\text { Hussain, } \\
(2020)\end{array}$ & + \\
\hline 2 & $\begin{array}{l}\text { Multiple } \\
\text { Directorships } \\
\text { multiple directorships over total } \\
\text { number of directors }\end{array}$ & $\begin{array}{l}\text { Velte } \\
(2021)\end{array}$ & + \\
\hline 3 & $\begin{array}{l}\text { Related Party } \\
\text { Transaction }\end{array}$ & RPT & $\begin{array}{l}\text { Volume of transactions between } \\
\text { companies in the same economic group. }\end{array}$ & $\begin{array}{l}\text { Habib, } \\
\text { Bhuiyan, } \\
\text { and Wu } \\
(2021)\end{array}$ & - \\
\hline 4. & Profitability & PFT & $\begin{array}{l}\text { Measured as profit after tax scaled by } \\
\text { total asset }\end{array}$ & $\begin{array}{l}\text { Hasnan, } \\
\text { Razali, and } \\
\text { Hussain, } \\
\text { (2020) }\end{array}$ & - \\
\hline
\end{tabular}




\section{RESULTS PRESENTATION AND DISCUSSION}

Table 2 presents the descriptive statistics of the variables investigated. The table shows the mean values and standard deviation of the restatement firms and the non-restatement firms. The table also uses a t-test statistics to compare the mean values of the two groups.

From the table it is observed that 66.5 per cent of. board members of the sampled firms that restated are multiple directors compared to 58.0 per cent non-restatement firms. The mean difference is also statistically significant $(t=2.519, \mathrm{p}<0.05)$. Also, more restatement than non-restatement firms have higher volume of related party transactions. On the average restating firms recorded relate party transactions of 27.5 (billion Naira) with a mean difference of 9.64 (billion Naira). The $\mathrm{t}$-test comparison. is also statistically significant $(t=2.996, \mathrm{p}<0.05)$. However, there is no significant statistical difference of mean for profitability $(\mathrm{t}=-1.067, \mathrm{p}>0.05)$. The descriptive result indicates that, on average, the profitability level of firms that restated their corporate financial reports is less than those of non-restating firms.

Table 2: Descriptive Analysis

\begin{tabular}{llllllll}
\hline & \multicolumn{2}{l}{$\begin{array}{l}\text { Restatement } \\
\text { (n=24) }\end{array}$} & Firms & \multicolumn{2}{l}{$\begin{array}{l}\text { Non-Restatement } \\
\text { Firms (n=46) }\end{array}$} \\
\hline Variable & Mean & Std. Dev. & Mean & Std. Dev. & Mean Diff & t-value & p-value \\
\hline Multiple Directorship & 0.665042 & .0 .1536641 & 0.580261 & 0.1221824 & 0.08478 & 2.519 & 0.005 \\
Related Party Transaction & 27.46562 & 16.424699 & 17.81826 & 10.449904 & 9.64736 & 2.996 & 0.013 \\
Profitability & 0.151067 & 0.1095479 & 0.176085 & 0.0835397 & 0.02502 & -1.067 & 0.054 \\
\hline
\end{tabular}

The logistic regression analysis results on the relationship between, accounting restatement, multiple directorship and related party transactions are shown in Table 3. The result of the chisquare value from the Omnibus Test of Model Coefficients shows that the overall indication of the goodness-of-fit test is highly significant at $\left(\mathrm{X}^{2}=12.3, \mathrm{df}=3 ; \mathrm{p}=0.000\right)$. The implies that the model is able to distinguish between restatement and non-restatement firms. Further, Nagelkerke $\mathrm{R} 2$ of 0.223 indicates that independent variables are able to explain 22.3 percent of the variation in the incidence of accounting restatement. In addition, the model, as a whole, correctly classified 72.9 per cent of the cases into two groups: restatement firms 41.7 per cent and non-restatement firms 89.1 per cent.

As regards individual vairables, MDS is found to have a positive but insignificant association with the incidence of accounting restatement at 5\% significant level $\left(\beta_{1} M D S i t=4.219, p>0.05\right)$. The result met our a priori expectation and is consistent with prior studies such as Velte (2021) and Carpenter and Westphal (2001). However, this result is not consistent with study by Fich and Shivdasani (2006) who are proponents of busyness hypothesis. The implication of the result is that the directors who are also directors in other firms bring their experience to bear in effective role of monitoring management financial reporting activities. 
With regard to the RPT variable, the result indicates a positive and significant relationship with the incidence of accounting restatement $\left(\beta_{2}\right.$ RPTit $\left.=0.054, p=0.019\right)$. This indicates that higher volume of related party transactions does not increase the incidence of accounting restatement. The result did not meet our a priori expectation but is consistent with previous studies such as Mahenthiran (2020), Chap, Kohlbeck, and Mayhew (2017), and Henry, Gordon, Reed and Louwers (2012). The implication of the result if that the volume of related party transaction does not have the capacity to induce accounting misstatements.

Table 3: Logistic Regression Test Result

\begin{tabular}{|c|c|c|c|c|c|c|}
\hline Variables & B & S. E & Wald & $\begin{array}{l}\text { P- } \\
\text { value }\end{array}$ & $\begin{array}{l}\text { Exp } \\
\text { (B) }\end{array}$ & $\begin{array}{l}\text { A Priori } \\
\text { Expectation }\end{array}$ \\
\hline Multiple Directorship & 4.219 & 2.167 & 3.790 & 0.052 & 67.980 & + \\
\hline Related Party Transaction & 0.054 & 0.023 & 5.519 & 0.019 & 1.055 & - \\
\hline Profitability & 1.461 & 3.408 & 0.184 & 0.668 & 4.312 & + \\
\hline Constant & 4.720 & 1.662 & 8.061 & 0.005 & 0.009 & \\
\hline
\end{tabular}

$\mathrm{n}=140$; Nagelkerke R2 $=0.223$

Classification overall percentage $=72.9$

Restatement firms $=41.7$

Non-restatement firms $=89.1$

Finally, the coefficient of the profitability control variable PFT is found to be positive but statistically not significant at $5 \%\left(\beta_{3}\right.$ PFTit $\left.=1.461, p=0.668\right)$. The result meets our a priori exection and is consistent with previous studies by Efendi et al. (2007) and Peterburgskey (2012), The implication of the result is that profitability cannot be deemed a significant determinant of the incidence of accounting restatement.

\section{CONCLUSION AND RECOMMENDATION}

The study was carried out to examine multiple directorship and related party transactions as they relate to the incidence of accounting restatement in Nigeria. The scope of the study was financial statements of 14 listed industrial goods companies for the period 2011 to 2020. Findings of the study show that related party transactions have a positive and significant association with accounting restatement. The study further revealed that multiple directorship and firm profitability are not significant predictors for the incidence of accounting restatement among listed industrial goods companies in Nigeria. The study concludes that both board attributes of multiple directorship and firm operational characteristics such as related party transactions and profitability are important in determining the incidence of accounting restatement. The study recommends that firms should encourage sound corporate governance mechanisms to enhance effective monitoring and internal control processes to minimize the incidence of accounting misstatements. 
European Journal of Accounting, Auditing and Finance Research

Vol.10, No. 2, pp.52-63, 2022

Print ISSN: 2053-4086(Print),

Online ISSN: 2053-4094(Online)

\section{References}

Abdulmalik, S., \& Ahmad, A. C. (2016). Audit fees, corporate governance mechanisms and

financial reporting quality in Nigeria. DLSU Business \& Economics Review, 26(1), 122-135. https://www.dlsu.edu.ph/wpcontent/uploads/2019/03/9Abdulmalik-072516.pdf

Anderson, K. \& Yohn, T. (2002). The effect of $10 \mathrm{~K}$ restatements on firm value, information

asymmetries, and investors' reliance on earnings. Information Asymmetries, and Investors' Reliance on Earnings (September 2002).

Badawi, I. M. (2008). Motives and consequences of fraudulent financial reporting. A paper presented at the 17th annual convention of the global awareness society international, May, 2008, San Fracisco, USA

Baccouche, S., Hadriche, M., \& Omri, A. (2014). Multiple directorships and board meeting frequency: Evidence from France. Applied Financial Economics, 24(14), 983-992.

Barzuza, M., \& Quinn, C. (2017). Board Interlocks and outside directors' protection, Journal of Legal Studies, 46, 129-160.

Beasley, M. S. (1996). An empirical analysis of the relation between the board of director composition and financial statement fraud. The Accounting Review, 71(4), 443-465

Carpenter, M., \& Westphal, J. (2001) The strategic context of external network ties: examining the impact of director appointments on board involvement in strategic decision making. Academy of Management Journal, 4, 639-660.

Companies and Allied Matters Act (2020). Companies and Allied Matters Act 2020. Corporate Affairs Commission, Abuja. FGN.

Efendi, J., Srivastava, A., \& Swanson, E.P. (2004). Why do corporate managers misstate financial statements? The role of option compensation, corporate governance and other factors, working paper, Texas A\&M University

Elyasiani, E., \& Zhang, , L. (2015) Bank holding company performance, risk, and "busy" board of directors. Journal of Banking and Finance, 60, 239-251.

Enofe, A.E., Mgbame, C., Otuya,mS., \& Ovie, C. (2013). Audit report and going concern assumption in the face of corporate scandals in Nigeria. Research Journal of Finance and Accounting, 4(11), 149-155

Fich, M. \& Shivdasani, A. (2006). Are busy boards effective monitors? Journal of Finance, 61(2), 689-724.

FRC. (2014). National code of corporate governance 2014. In Financial Reporting Council of Nigeria: Nigeria

Gordon, E. A.., Henry, E. \& Palia, D. (2004). Related party transactions and corporate governance. Advances in Financial Economics, 9, 1-28.

Habib, A., Bhuiyan, B U., \& Wu, J. (2021). Corporate governance determinants of financial restatements: A Meta-Analysis. The International Journal of Accounting, 56(01), 21-35. https://doi.org/10.1142/S1094406021500025

Hasnan, H., \& Marzuki, S. (2017). Board of directors' characteristics and financial restatement. JMFR, 14(1), 12-21 
European Journal of Accounting, Auditing and Finance Research

Vol.10, No. 2, pp.52-63, 2022

Print ISSN: 2053-4086(Print),

Online ISSN: 2053-4094(Online)

Hasnan, S., Razali, M.H., \& Hussain, A.R. (2020). The effect of corporate governance and firm specific characteristics on the incidence of financial restatement. Journal of Financial Crime, 6(2), 111-132 DOI 10.1108/JFC-06-2020-0103

Henry, E., Gordon, E. A., Reed, B., \& Louwers, T. (2012). The role of related party transactions in fraudulent financial reporting. Journal of Forensic \& Investigative Accounting, 4(1), 186-213.

Institute of Chartered Accountants of Nigeria. (2014). Advanced Audit and Assurance, Study Pack, V.I publishers, Lagos.

Jehu, P., \& Ibrahim, M.A. (2020). The effect of audit committee characteristics on financial restatements in Nigeria. Nigerian Journal of Accounting and Finance, 12(1), 1-19

Jensen, M. C., \& Meckling, W. H. (1976). Theory of the firm: managerial behavior, agency costs and ownership structure. Journal of Financial Economics, 3(4), 305-360.

Khanna, T., \& Palepu, K. (2000) Is group affiliation profitable in emerging markets an analysis of diversified Indian business groups. Journal of Finance, 55(2), 867-891

Kohlbeck, M. J., \& Mayhew, B. W. (2017). Are Related Party Transactions Red Flags? Available at SSRN: https://ssrn.com/abstract=2427439 or http://dx.doi.org/10.2139/ssrn.2427439

Mahenthiran. I. (2020). The effect of board links, audit partner tenure, and related party transactions on misstatements: evidence from Chile. International Journal of Financial Studies. 8(4), 78. https://doi.org/10.3390/ijfs8040078

Morck, R., Shleifer, A., \& Vishny, R. (1988). Management ownership and market valuation an empirical analysis. Journal of Financial Economics, 20(1), .293-315.

Nigeria Codes of Corporate Governance (2018). Nigerian codes of Corporate Governance. Financial Reporting Council of Nigeria.

Nigerian Stock Exchange (2021) Market Reports. Available online at www.nigerianstockexchange.com/Issuers-section/listing...company/industry

Odia, J. (2007). Creative accounting and its implications for financial reporting in Nigeria. Nigeria Journal of Business Administration, 8 (1/2), 11-28

Okeoma, E.C., \& Kiabel, D. (2020). Audit firm size and earnings restatement of quoted consumer goods manufacturing firms in Nigeria. RSU Journal of Strategic and Internet Business, 5(2), 1153-1163

Okolie, A. O., \& Agboma, D. J. (2008. The impact of environmental dynamics on the accounting profession in Nigeria. Journal of Business Administration and Management, 3(1), 70 - 75.

Peterburgskey, S. (2012). In search of responsible CEOs: The case of CEO with non-profit experience. Journal of Business Research, 65(9), 1378-1383.

Pfeffer, J., \& Salancik, G. R. (1978). The external control of organizations: A resource dependence perspective. New York: Harper and Row.

Rasyid, A., \& Ardana, C. (2014). Corporate governance, audit firm size and restated financial statement in Indonesia stock exchange. Corporate Board Role Duties and Composition, $10(2), 77-84$.

Schroeder, M. (2001). SEC list of accounting fraud probes grows. Wall Street Journal, (July6), 11.

ECRTD-UK: https://www.eajournals.org/

Journal level DOI: https://doi.org/10.37745/ejaafr.2013 
European Journal of Accounting, Auditing and Finance Research

Vol.10, No. 2, pp.52-63, 2022

Print ISSN: 2053-4086(Print),

Online ISSN: 2053-4094(Online)

Ukarin, S. (2021). Accounting Manipulation and timeliness of financial reporting. Unpublished Ph.D. seminar. Presented at the department of Accounting. University of Benin, Benin City.

Uniamikogbo E., Ayorinde, B., \& Oyewo, B. (2014). Audit committee multiple directorships and financial reporting quality in Nigeria: An evaluation of the interconnectedness using empirical evidence, Mediterranean Journal of Social Sciences, 5(20), 627-639

Utari, N.W., Rustiarini, S., \& Dewi, P.U. (2021). Board characteristic and financial restatement. Jurnal Keuangan dan Perbankan, 25(3), 492 - 507

Velte, P. (2021). The link between corporate governance and corporate financial misconduct. A review of archival studies and implications for future research. Management Review Quarterly, 3(1), 111-124

Yamane, T. (1967). Statistics, An Introductory Analysis, 2nd Ed., New York: Harper and Row. 